\title{
Carbonic anhydrase inhibitors: Gd(III) complexes of DOTA- and TETA-sulfonamide conjugates targeting the tumor associated carbonic anhydrase isozymes IX and XII
}

Citation for published version (APA):

Rami, M., Montero, J-L., Dubois, L., Lambin, P., Scozzafava, A., Winum, J-Y., \& Supuran, C. T. (2010). Carbonic anhydrase inhibitors: Gd(III) complexes of DOTA- and TETA-sulfonamide conjugates targeting the tumor associated carbonic anhydrase isozymes IX and XII. New Journal of Chemistry, 34(10), 21392144. https://doi.org/10.1039/c0nj00214c

Document status and date:

Published: 01/01/2010

DOI:

10.1039/c0nj00214c

Document Version:

Publisher's PDF, also known as Version of record

Document license:

Taverne

Please check the document version of this publication:

- A submitted manuscript is the version of the article upon submission and before peer-review. There can be important differences between the submitted version and the official published version of record. People interested in the research are advised to contact the author for the final version of the publication, or visit the DOI to the publisher's website.

- The final author version and the galley proof are versions of the publication after peer review.

- The final published version features the final layout of the paper including the volume, issue and page numbers.

Link to publication

\footnotetext{
General rights rights.

- You may freely distribute the URL identifying the publication in the public portal. please follow below link for the End User Agreement:

www.umlib.nl/taverne-license

Take down policy

If you believe that this document breaches copyright please contact us at:

repository@maastrichtuniversity.nl

providing details and we will investigate your claim.
}

Copyright and moral rights for the publications made accessible in the public portal are retained by the authors and/or other copyright owners and it is a condition of accessing publications that users recognise and abide by the legal requirements associated with these

- Users may download and print one copy of any publication from the public portal for the purpose of private study or research.

- You may not further distribute the material or use it for any profit-making activity or commercial gain

If the publication is distributed under the terms of Article 25fa of the Dutch Copyright Act, indicated by the "Taverne" license above, 


\title{
Carbonic anhydrase inhibitors: Gd(III) complexes of DOTA- and TETA-sulfonamide conjugates targeting the tumor associated carbonic anhydrase isozymes IX and XII
}

\author{
Marouan Rami, ${ }^{a}$ Jean-Louis Montero, ${ }^{a}$ Ludwig Dubois, ${ }^{b}$ Philippe Lambin, ${ }^{b}$ \\ Andrea Scozzafava, ${ }^{c}$ Jean-Yves Winum* ${ }^{a}$ and Claudiu T. Supuran*c
}

Received (in Montpellier, France) 22nd March 2010, Accepted 28th April 2010

DOI: $10.1039 / \mathrm{c} 0 \mathrm{nj00214c}$

\begin{abstract}
Gd(III)-sulfonamide complexes incorporating macrocyclic rings of the DOTA/TETA type have been prepared and assayed for the inhibition of the metalloenzyme carbonic anhydrase (CA, EC 4.2.1.1). The cytosolic isoform, CA I, was poorly inhibited, whereas cytosolic CA II and transmembrane, tumor-associated CA IX and XII were inhibited in the low nanomolar range by the Gd(III) complexes. Magnetic susceptibility and relaxivity measurements proved that the Gd(III) complexes have comparable parameters to those of clinically used MRI contrast agents like Dotarem, Prohance and Omniscan in aqueous solution. Some Gd(III) complexes were investigated for the inhibition of extracellular tumor acidification in two cell lines overexpressing CA IX, the colorectal HT-29 cell line and the cervical HeLa carcinoma cell line. In both tumor types, a slight but significant reduction of tumor acidosis was detected. Gd(III)-sulfonamide conjugates may thus be of interest for developing imaging techniques or novel treatment strategies for the management of hypoxic tumors overexpressing extracellular CA isozymes such as CA IX and XII.
\end{abstract}

\section{Introduction}

$\alpha$-Carbonic anhydrases (CAs, EC 4.2.1.1) are widespread metalloenzymes in higher vertebrates, including humans. ${ }^{1,2}$ 16 isozymes have been characterized to date that differ in their sub-cellular localization, catalytic activity and susceptibility to different classes of inhibitors. There are cytosolic isozymes (CA I, CA II, CA III, CA VII and CA XIII), membrane bound examples (CA IV, CA IX, CA XII and CA XIV), and mitochondrial (CA VA and CA VB) and secreted (CA VI) isoforms. $^{3-9}$ Three acatalytic forms, called CA-related proteins (CARPs) (CARP VIII, CARP X and CARP XI) are also known. ${ }^{1}$ In humans, CAs are present in a large variety of tissues, such as the gastrointestinal tract (GI), the reproductive tract, the nervous system, kidneys, lungs, skin and eyes. ${ }^{1,2,6,10-12}$ Most CAs are very efficient catalysts for the reversible hydration of carbon dioxide to bicarbonate and protons $\left(\mathrm{CO}_{2}+\mathrm{H}_{2} \mathrm{O} \rightleftharpoons \mathrm{HCO}_{3}{ }^{-}+\mathrm{H}^{+}\right)$, which is the only physiological reaction in which they are involved. ${ }^{1}$

Many CA isoforms are involved in critical physiological processes such as respiration and acid-base regulation, electrolyte secretion, bone resorption, calcification and

\footnotetext{
${ }^{a}$ Institut des Biomolécules Max Mousseron (IBMM), UMR 5247 CNRS-UM1-UM2, Bâtiment de Recherche Max Mousseron, Ecole Nationale Supérieure de Chimie de Montpellier,

8 rue de l'Ecole Normale, 34296 Montpellier Cedex, France.

E-mail: jean-yves.winum@univ-montp2.fr

${ }^{b}$ Maastricht Radiation Oncology (MaastRO) Lab, GROW-School for Oncology and Developmental Biology, University of Maastricht, Maastricht, The Netherlands

${ }^{c}$ Università degli Studi di Firenze, Polo Scientifico, Laboratorio di Chimica Bioinorganica, Rm. 188, Via della Lastruccia 3, 50019 Sesto Fiorentino (Florence), Italy.

E-mail: claudiu.supuran@unifi.it
}

biosynthetic reactions, which require bicarbonate as a substrate (lipogenesis, gluconeogenesis and ureagenesis). ${ }^{1}$ Two of them, CA IX and CA XII, are predominantly associated with and overexpressed in many tumors, being involved in critical processes connected with cancer progression and responses to therapy. ${ }^{1-3,11-14} \mathrm{CA}$ IX is confined to a few normal tissues (stomach and body cavity lining) but it is ectopically induced and highly overexpressed in many solid tumor types through strong transcriptional activation by hypoxia, accomplished via the hypoxia inducible factor-1 (HIF-1) transcription factor, as shown schematically in Fig. 1.,3-5,12-14

The expression of CA XII was detected in all tumor categories, although the mean staining intensity was weaker than for CA IX in all groups, except renal clear cell carcinomas. ${ }^{11}$ These two enzymes are multidomain proteins with the CA domain situated outside the cell and their $\mathrm{CO}_{2}$ hydrase catalytic activity being medium-to-high for CA XII and very high for CA IX. ${ }^{8,15}$ The X-ray crystal structure of CA IX has only recently been reported our group, ${ }^{15}$ allowing for interesting drug design campaigns. Sulfonamides and their isosteres (sulfamates and sulfamides) among others, constitute a well-known class of CA inhibitors (CAIs), with some derivatives, such as acetazolamide (AAZ) or ethoxzolamide (EZA), having been used clinically for a long time for the management of CA mis-balances different from cancer-related examples. ${ }^{1-7}$

Many new inhibitors of both CA IX and XII have been reported in recent years when connections between these CA isozymes and hypoxic tumors began to emerge, ${ }^{1-10}$ with many of these new generation inhibitors being specifically designed for targeting tumor-associated CAs. Indeed, classical CAIs, such as $\mathbf{A A Z}$ and $\mathbf{E Z A}$, indiscriminately inhibit all $\mathrm{CA}$ isoforms, ${ }^{1}$ and this may constitute a disadvantage when only tumor-associated examples must be targeted. 


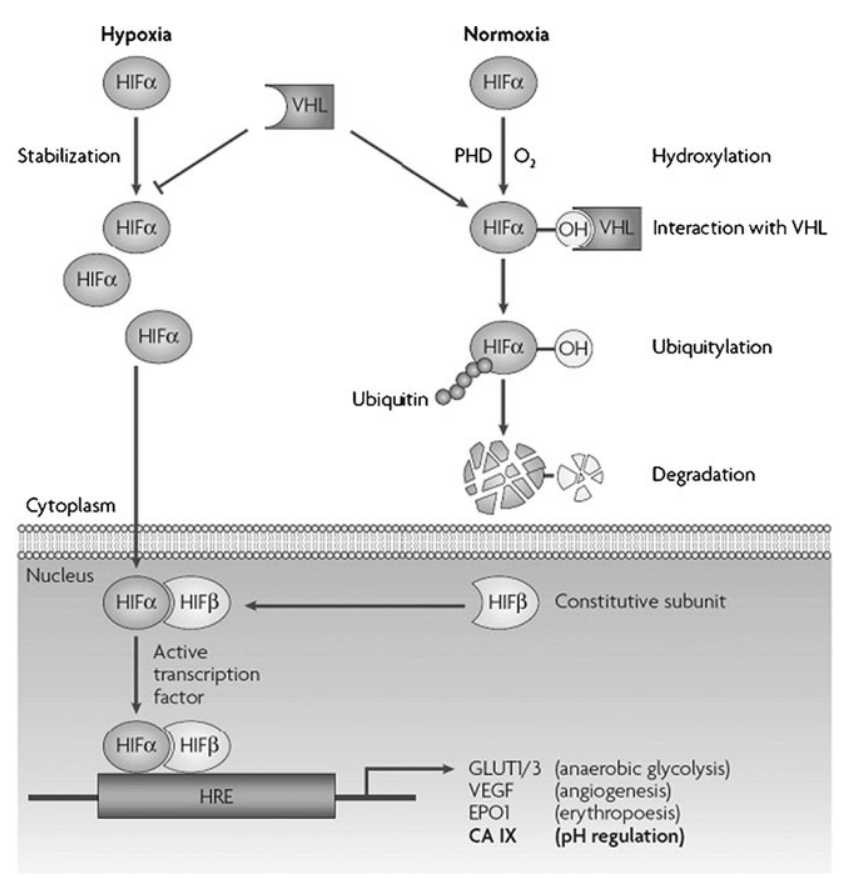

Fig. 1 The mechanism of hypoxia-induced gene expression mediated by the HIF transcription factor, leading to CA IX overexpression in hypoxic tumors $(\mathrm{HRE}=$ hypoxia responsive element; $\mathrm{PHD}=$ prolyl hydroxylase; VHL $=$ von Hippel-Lindau protein $).{ }^{1}$

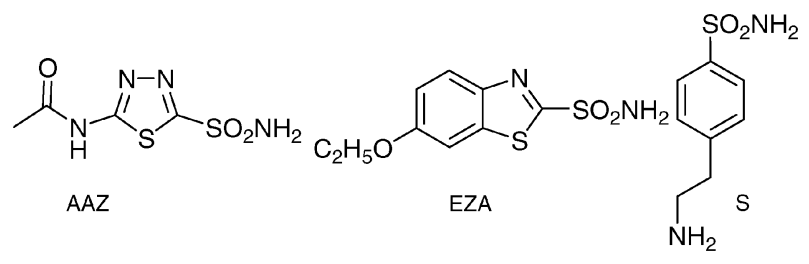

Recently our group reported some interesting CA IX inhibitors (possessing fluoresceinthioureido moieties in their molecules) that were critical for assessing the in vivo role of CA IX/XII in tumor acidification processes. ${ }^{16-18}$ Such inhibitors were shown to bind to CA IX only under hypoxia in vivo in cell cultures or in animals bearing human tumors, followed by a reduction of extracellular $\mathrm{pH}$ acidification in the tumor tissues, ${ }^{16-18}$ properties which may be exploited for designing diagnostic tools for the treatment or imaging of hypoxic tumors. $^{16-20}$ Indeed, we $\mathrm{e}^{16-18}$ and Neri's group ${ }^{19,20}$ recently published proof of concept studies showing the possibility of using CA IX/XII inhibitors both for the imaging and treatment of hypoxic tumors.

Continuing our studies in the design of CA IX/XII inhibitors, we report here conjugates of sulfonamides incorporating macrocyclic rings that can bind gadolinium(III), a metal ion possessing interesting properties for the magnetic resonance imaging (MRI) of tumors and other diseases. ${ }^{21-23}$ Indeed, paramagnetic lanthanide(III) complexes are used in two major classes of MRI applications as contrast agents: the wellestablished class of Gd-based agents and the emerging class of chemical exchange saturation transfer (CEST) agents. ${ }^{24} \mathrm{~A}$ Gd-based complex increases the water signal by enhancing the longitudinal relaxation rate of water protons, whereas CEST agents decrease water signal as a consequence of the transfer of saturated magnetization from the exchangeable protons of the agent. $^{24}$ Here, we report that Gd(III)-incorporating conjugates of sulfonamides show a strong inhibition of the tumor-associated CA isoforms CA IX and XII, decrease tumor acidifications in cell cultures of HT-29 colorectal and HeLa cervical cancer cell lines, and can also be used for MRI purposes, making this class of conjugates of particular interest for further studies.

\section{Experimental}

\section{Synthesis}

Sulfonamide ligands $\mathbf{1 a - c}$ and $\mathbf{2 a - c}$ were synthesized as previously described by our group. ${ }^{25}$ A solution of $\mathrm{Gd}(\mathrm{III})$ chloride hexahydrate $(1.1 \mathrm{mmol})$ in de-ionized water $(2 \mathrm{ml})$ was added dropwise to a solution of ligand $\mathbf{1 a}-\mathbf{c}(1 \mathrm{mmol})$ or 2a-c $(1 \mathrm{mmol})$ dissolved in water $(50 \mathrm{ml})$. The $\mathrm{pH}$ of the aqueous solution was adjusted and maintained at $\mathrm{pH} 6.8$ by the constant addition of $2 \mathrm{~N} \mathrm{NaOH}$. The solution was vigorously stirred at room temperature and the formation of the gadolinium complex monitored by ESI-MS. After $2 \mathrm{~h}$, the solution was concentrated to approximately $10 \mathrm{ml}$ and acetonitrile $(50 \mathrm{ml})$ was added. The precipitate was filtered, washed with water and ether, and dried over $\mathrm{P}_{2} \mathrm{O}_{5}$ to give the expected gadolinium complexes $(\mathbf{3 a}-\mathbf{c})$ or $(\mathbf{4 a}-\mathbf{c})$ quantitatively as a white solid.

3a: $\mathrm{mp}>205{ }^{\circ} \mathrm{C}, \mathrm{MS}\left(\mathrm{ESI}^{+} / \mathrm{ESI}^{-}\right) \mathrm{m} / z: 728.3(\mathrm{M}+\mathrm{H})^{+}$, 750.3, $(\mathrm{M}+\mathrm{Na})^{+}, 726.2(\mathrm{M}-\mathrm{H})^{-}$; $\operatorname{HRMS}(\mathrm{M}+\mathrm{H})^{+}$calc. for $\mathrm{C}_{23} \mathrm{H}_{34} \mathrm{GdN}_{6} \mathrm{O}_{9} \mathrm{~S}$ 728.1349, found 728.11346; 3b: $\mathrm{mp}>205{ }^{\circ} \mathrm{C}, \mathrm{MS}\left(\mathrm{ESI}^{+} / \mathrm{ESI}^{-}\right) m / z: 742.15(\mathrm{M}+\mathrm{H})^{+}$, 764.16, $(\mathrm{M}+\mathrm{Na})^{+}, 740.27(\mathrm{M}-\mathrm{H})^{-} ; \operatorname{HRMS}(\mathrm{M}+\mathrm{H})^{+}$ calc. for $\mathrm{C}_{24} \mathrm{H}_{36} \mathrm{GdN}_{6} \mathrm{O}_{9} \mathrm{~S}$ 742.1505, found 742.1508; 3c: $\mathrm{mp}>205{ }^{\circ} \mathrm{C}, \mathrm{MS}\left(\mathrm{ESI}^{+} / \mathrm{ESI}^{-}\right) \mathrm{m} / z: 714.25(\mathrm{M}+\mathrm{H})^{+}$, $736.21(\mathrm{M}+\mathrm{Na})^{+}, 712.19(\mathrm{M}-\mathrm{H})^{-} ; \operatorname{HRMS}(\mathrm{M}+\mathrm{H})^{+}$ calc. for $\mathrm{C}_{22} \mathrm{H}_{32} \mathrm{GdN}_{6} \mathrm{O}_{9} \mathrm{~S}$ 714.1192, found 714.1196; 4a: $\mathrm{mp}>205{ }^{\circ} \mathrm{C}, \mathrm{MS}\left(\mathrm{ESI}^{+} / \mathrm{ESI}^{-}\right) m / z: 778.30(\mathrm{M}+\mathrm{Na})^{+}$, $778.21(\mathrm{M}+\mathrm{Na})^{+}, 754.35(\mathrm{M}-\mathrm{H})^{-} ; \operatorname{HRMS}(\mathrm{M}+\mathrm{H})^{+}$ calc. for $\mathrm{C}_{25} \mathrm{H}_{38} \mathrm{GdN}_{6} \mathrm{O}_{9} \mathrm{~S} 756.1662$, found $756.1665 ; 4 \mathbf{b}$ : $\mathrm{mp}>205{ }^{\circ} \mathrm{C}, \mathrm{MS}\left(\mathrm{ESI}^{+} / \mathrm{ESI}^{-}\right) m / z: 770.07(\mathrm{M}+\mathrm{H})^{+}$, $792.19(\mathrm{M}+\mathrm{Na})^{+}, 768.12(\mathrm{M}-\mathrm{H})^{-}$; $\operatorname{HRMS}(\mathrm{M}+\mathrm{H})^{+}$ calc. for $\mathrm{C}_{26} \mathrm{H}_{40} \mathrm{GdN}_{6} \mathrm{O}_{9} \mathrm{~S} 770.1818$, found 770.1816 ; $4 \mathrm{c}$ : $\mathrm{mp}>205{ }^{\circ} \mathrm{C}, \mathrm{MS}\left(\mathrm{ESI}^{+} / \mathrm{ESI}^{-}\right) m / z: 742.21(\mathrm{M}+\mathrm{H})^{+}$, 764.11, $(\mathrm{M}+\mathrm{Na})^{+}, 740.33(\mathrm{M}-\mathrm{H})^{-} ; \operatorname{HRMS}(\mathrm{M}+\mathrm{H})^{+}$ calc. for $\mathrm{C}_{24} \mathrm{H}_{36} \mathrm{GdN}_{6} \mathrm{O}_{9} \mathrm{~S} 742.1505$, found, 742.1507 .

\section{Magnetic susceptibility measurements}

Magnetic susceptibility data were collected using a Quantum Design MPMS-XL SQUID magnetometer working in the temperature range $1.8-350 \mathrm{~K}$ up to $5 \mathrm{~T}$. The magnetic data were corrected for the sample holder and the diamagnetism contributions calculated from Pascal's constants. ${ }^{26}$

\section{Relaxivity MRI protocols}

For each compound, 10 samples were prepared with gadolinium concentrations ranging from 0 to $1 \mathrm{mM}$ in steps of $0.1 \mathrm{mM}$. Measurements were performed on a $7 \mathrm{~T}$ Bruker Biospec 70/30 USR MRI system (Bruker Biospin GmbH, Ettlingen, Germany) 
interfaced to an AVANCE II console. A BGA12-S mini-imaging gradient system (maximum gradient strength $720 \mathrm{mT} \mathrm{m}^{-1}$, slew rate $6000 \mathrm{~T} \mathrm{~m}^{-1} \mathrm{~s}^{-1}$ ) was used, and images were acquired using a $7.2 \mathrm{~cm}$ inner diameter quadrature volume resonator.

Longitudinal relaxation rates $\left(R_{1}=1 / T_{1}\right)$ were determined using a series of inversion recovery measurements with increasing inversion times of 200, 500, 750, 1000, 1500, 2000, 2500 and $3500 \mathrm{~ms}$. Repetition and echo times were $7500 \mathrm{~ms}$ and $8.2 \mathrm{~ms}$, respectively. Transverse relaxation rates $\left(R_{2}=1 / T_{2}\right)$ were measured using a multi-slice, multi-echo spin echo sequence, with a repetition time of $7500 \mathrm{~ms}$, echo times ranging from 10 to $120 \mathrm{~ms}$ and an echo interval of $10 \mathrm{~ms}$. For all images, 5 slices were recorded with a slice thickness of $1 \mathrm{~mm}$ and an interslice distance of $1.5 \mathrm{~mm}$. The field-of-view was $7 \times 7 \mathrm{~cm}^{2}$ and the acquisition matrix was $256 \times 256$, resulting in a spatial resolution of $0.27 \times 0.27 \times 1.0 \mathrm{~mm}^{3}$.

Regions of interest were drawn manually in MRIcro. ${ }^{27}$ All further data processing was performed in Matlab (The MathWorks, Natick, MA). $R_{1}$ values were determined by non-linear curve fitting of the inversion recovery signal intensity function (eqn 1$):^{28}$

$$
S=S_{0}\left(1-2 \mathrm{e}^{-T_{\mathrm{I}} R_{1}}+\mathrm{e}^{-T_{\mathrm{R}} R_{1}}\right)
$$

using the Levenberg-Marquardt optimization algorithm. $S_{0}$ is a scaling factor including proton density, pre-amplifier gain and echo time. $T_{\mathrm{I}}$ and $T_{\mathrm{R}}$ are the inversion and repetition times, respectively. $R_{2}$ values were determined analogously by non-linear fitting of the spin echo signal intensity function (eqn 2):

$$
S=S \mathrm{e}^{-T_{\mathrm{E}} R_{2}}
$$

Here, $S_{0}$ is a scaling factor depending on proton density, pre-amplifier gain and repetition time, and $T_{\mathrm{E}}$ is the echo time. The longitudinal relaxivity, $r_{1}$, and transverse relaxivity, $r_{2}$, were given by the slope of a linear fit of $R_{1}$ and $R_{2} v s$. gadolinium concentration, respectively.

\section{CA inhibition}

An Applied Photophysics stopped-flow instrument was used for assaying the CA-catalysed $\mathrm{CO}_{2}$ hydration activity. ${ }^{29}$ Phenol red (at a concentration of $0.2 \mathrm{mM}$ ) was used as an indicator, working at an absorbance maximum of $557 \mathrm{~nm}$ with $20 \mathrm{mM}$ HEPES (pH 7.5) as the buffer and $20 \mathrm{mM} \mathrm{Na}_{2} \mathrm{SO}_{4}$ (for maintaining constant the ionic strength), to follow the initial rates of the CA-catalyzed $\mathrm{CO}_{2}$ hydration reaction for a period of $10-100 \mathrm{~s}$. The $\mathrm{CO}_{2}$ concentrations ranged from 1.7 to $17 \mathrm{mM}$ for the determination of the kinetic parameters and inhibition constants. For each inhibitor, at least six traces of the initial $5-10 \%$ of the reaction were used for determining the initial velocity. The uncatalyzed rates were determined in the same manner and subtracted from the total observed rates. Stock solutions of inhibitor $(0.1 \mathrm{mM})$ were prepared in distilled and de-ionized water, and dilutions down to $0.01 \mathrm{nM}$ were undertaken thereafter with further distilled and de-ionized water. Inhibitor and enzyme solutions were pre-incubated together for $15 \mathrm{~min}$ at room temperature prior to assay in order to allow for the formation of the E-I complex. The inhibition constant $\left(K_{\mathrm{I}}\right)$ was obtained by non-linear least-squares methods using PRISM 3, as reported earlier, ${ }^{25}$ and represent the mean from at least three different determinations. $K_{\mathrm{I}}$ is the equilibrium constant for the dissociation of the E-I complex.

\section{Cell culture and $\mathrm{pH}$ experiments}

Exponentially growing colorectal (HT-29, ATCC HTB-38) and cervical (HeLa, ATCC CCL-2) carcinoma cells were cultured in Dulbecco's modified Eagle's medium supplemented with $10 \%$ fetal bovine serum. Hypoxic conditions were maintained in a hypoxic culture chamber (MACS VA500 micro-aerophilic workstation, Don Whitley Scientific, Shipley, UK) consisting of an atmosphere of $0.2 \% \mathrm{O}_{2}, 5 \% \mathrm{CO}_{2}$ and residual $\mathrm{N}_{2}$. In parallel, normoxic dishes were incubated in air with $5 \% \mathrm{CO}_{2}$. The $\mathrm{pH}$ of the culture medium was immediately measured at the end of each experiment and the data expressed as delta $\mathrm{pH}$ ( $\mathrm{pH}$ after incubation $-\mathrm{pH}$ before incubation). The Gd compounds were dissolved in PBS containing 10\% DMSO at a $100 \mathrm{mM}$ concentration and diluted in culture medium to a final concentration of $1 \mathrm{mM}$ just before adding to the cells. The cells were incubated with the compounds for $24 \mathrm{~h}$ during normoxia or hypoxia. In parallel, 4-aminoethylbenzenesulfonamide (S), a compound investigated earlier and shown to decrease tumor acidification, ${ }^{16}$ was used as a positive control in these experiments.

\section{Results and discussion}

\section{Chemistry}

Many sulfonamide/sulfamate/sulfamide CAIs have been reported as inhibitors of both CA IX and XII in recent years, in the search for derivatives with selectivity for tumorassociated enzymes over other CAs involved in crucial physiological processes. ${ }^{1-7}$ The compounds specifically designed for targeting tumor-associated isoforms may be classified as follows: (i) sulfonamides tagged with fluorescent or other moieties (e.g., complexed metal ions, stable free radicals, etc.), which make them useful for imaging purposes; ${ }^{16-18}$ (ii) positively- or negatively-charged compounds that cannot cross plasma membranes due to their charged character and thus inhibit selectively only extracellular CAs, among which are CA IX and XII; ${ }^{16,30}$ (iii) hypoxia-activatable compounds that exploit the reducing conditions of hypoxic tumors to convert an inactive prodrug into an active $\mathrm{CAI} ;{ }^{31}$ (iv) sugar-containing sulfonamides/sulfamates/sulfamides that, due to their highly hydrophilic character, do not easily cross membranes and thus possess an enhanced affinity for extracellular CAs, such as CA IX and XII; ${ }^{32-34}$ (v) diverse chemotypes other than the sulfonamides and their bioisosters, such as phenols, coumarins and other compounds, have recently been investigated as alternative CAIs to classical types of inhibitor. ${ }^{35}$ Among the different approaches mentioned above, we have observed that sulfonamides incorporating macrocyclic rings of the DOTA and TETA type, as well as their $\mathrm{Cu}$ (II) complexes, show excellent inhibitory activity and selectivity for tumor-associated CAs over cytosolic isoforms CA I and II. $^{25}$ We thus decided to prepare the Gd(III) derivatives of previously reported sulfonamides $\mathbf{1}$ and $\mathbf{2}$ in 

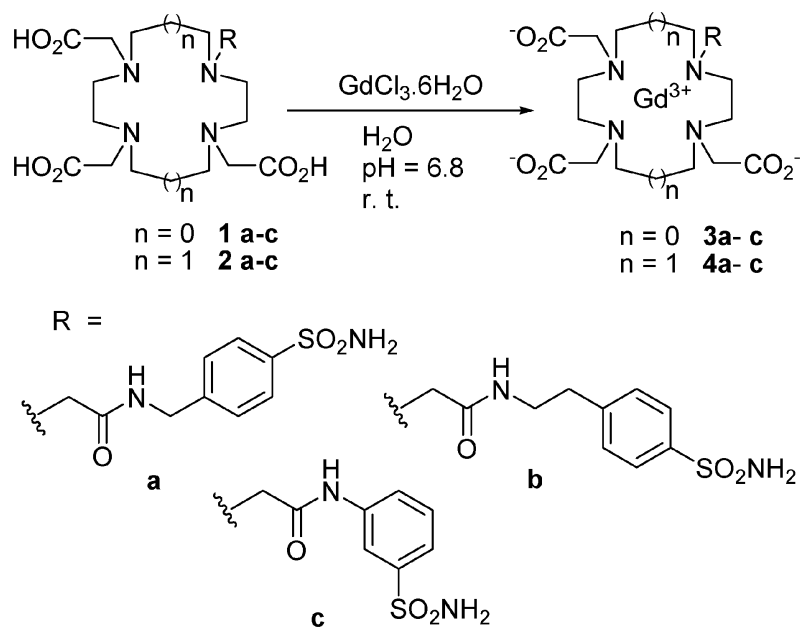

Scheme 1 The synthesis of Gd complexes 3a-c and $\mathbf{4 a - c}$.

order to investigate their interaction with these $\mathrm{CA}$ isoforms (Scheme 1). This is the first detailed study of lanthanidecontaining CAIs; these compounds being the first conjugate CAIs to be investigated as potential MRI agents.

The 12-membered ring DOTA and 14-membered ring TETA, known to easily complex lanthanide(III) ions ${ }^{22-24}$ were chosen as starting materials. These macrocycles also contain four pendant arms substituting the four endocyclic nitrogen atoms, three of which are of the methylcarboxylate type (for effective binding of the $\mathrm{Gd}(\mathrm{III})$ ions) and one of which is derivatized by means of aromatic sulfonamides, such as homosulfanilamide (3a and $\mathbf{4 a}$ ), 4-aminoethylbenzenesulfonamide (3b and $\mathbf{4 b}$ ) or metanilamide (3c and $\mathbf{4 c}$ ), which will assure an interaction with the enzyme. ${ }^{1,10}$ Indeed, sulfonamides in their deprotonated form complex $\mathrm{Zn}$ (II) ions from the CA active site and usually bind with low nanomolar affinity to many CA isoforms. ${ }^{1-10}$

Gd(III) complexes 3 and $\mathbf{4}$ were prepared from the corresponding macrocyclic ligands $\mathbf{1}$ and $\mathbf{2}$ by a reaction with Gd(III) salts under controlled $\mathrm{pH}$ conditions, as reported in the literature. ${ }^{21-24} \mathrm{Gd}(\mathrm{III})$-sulfonamide conjugates $\mathbf{3}$ and $\mathbf{4}$ were characterized by standard procedures that established their purity (of $>99 \%$ ) and stability in the conditions of the experiments performed in vitro and ex vivo (see later in the text). The absence of free gadolinium in the final compounds was confirmed by the detection of free Gd(III) using a xylenol orange indicator. ${ }^{23}$

\section{Magnetic properties and susceptibility measurements}

It was determined by means of magnetic measurements that complexes $\mathbf{3 b}$ and $\mathbf{4 b}$, as with all the Gd(III) derivatives investigated so $\mathrm{far}^{21-24}$ present a strong paramagnetic behavior (Fig. 2 and Table 1). The temperature dependencies of $\chi T$ and $1 / c$ measured for these two compounds are shown Fig. 2. For both compounds, the $\chi T$ values at room temperature were equal to 7.869 and $7.870 \mathrm{emu} \mathrm{K} \mathrm{mol}^{-1}$, which corresponds to the calculated value for the one $\mathrm{Gd}^{3+}$ ion (7.875 emu K mol ${ }^{-1}$ ) per molecule of complex. ${ }^{24}$

Table 1 summarizes the ionic longitudinal and transverse relaxivities for compounds $3 \mathbf{b}$ and $\mathbf{4 b}$, as determined at $7 \mathrm{~T}$ and

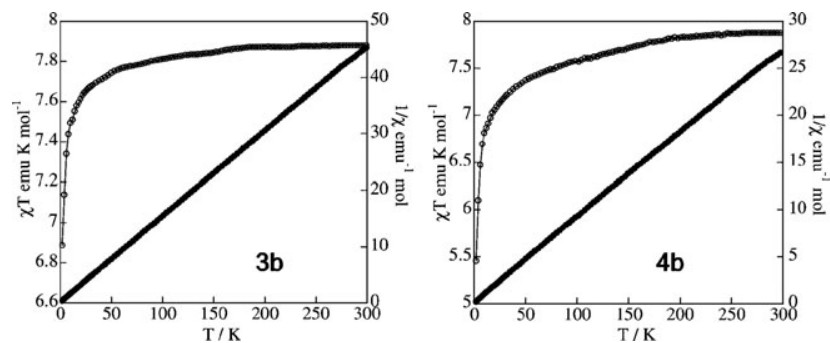

Fig. 2 Magnetic susceptibility measurements for compounds $\mathbf{3 b}$ and $\mathbf{4 b}$.

Table 1 Longitudinal $\left(r_{1}\right)$ and transverse $\left(r_{2}\right)$ relaxivities at $7 \mathrm{~T}$ and $20{ }^{\circ} \mathrm{C}$ for $\mathrm{Gd}(\mathrm{III})$ complexes $\mathbf{3 b}$ and $\mathbf{4 b}$

\begin{tabular}{lll}
\hline & $r_{1} / \mathrm{mM}_{\mathrm{Gd}}{ }^{-1} \mathrm{~s}^{-1}$ & $r_{2} / \mathrm{mM}_{\mathrm{Gd}}{ }^{-1} \mathrm{~s}^{-1}$ \\
\hline $\mathbf{3 b}$ & $3.6 \pm 0.2$ & $12.7 \pm 1.1$ \\
$\mathbf{4 b}$ & $3.2 \pm 0.1$ & $21.8 \pm 0.9$ \\
\hline
\end{tabular}

$20{ }^{\circ} \mathrm{C}$. The relaxivities of both compounds are in line with the known values of clinically-used MRI contrast agents like Dotarem, Prohance and Omniscan in aqueous solution. ${ }^{22-24}$ They are typical of compounds incorporating this paramagnetic ion, making these derivatives suitable for MRI purposes. ${ }^{24}$

\section{Carbonic anhydrase inhibition}

Inhibition data of four physiologically relevant CA isozymes, the cytosolic, ubiquitous CA I and II (off-targets), and the tumor-associated CA IX and XII, with compounds 1-4 are shown in Table 2. The inhibition of standard sulfonamides AAZ, EZA and $\mathbf{S}$ are also included in Table 2 for comparison. The data for ligands $\mathbf{1}$ and $\mathbf{2}$ were reported earlier. ${ }^{25}$ The following should be noted regarding CA inhibition with the gadolinium complexes investigated here.

(i) The slow cytosolic isoform hCA I was not effectively inhibited by Gd(III) complexes 3 and $\mathbf{4}$, which showed inhibition constants in the range $380-7700 \mathrm{nM}$. This is a positive feature for a compound which must show selectivity for the transmembrane isoforms and not inhibit too effectively the cytosolic examples, such as CA I. It is, however, interesting to note that the bulkier TETA derivatives were generally better hCA I inhibitors compared to the corresponding DOTA complexes. Furthermore, Gd(III) complexes 3 were generally weaker inhibitors compared to corresponding ligands $\mathbf{1}$ (except 3a) for the DOTA derivatives, whereas they were more inhibitory in the case of TETA complexes $\mathbf{4}$ (compared with 2). It is rather difficult to rationalize these data as no X-ray crystal structures of the adducts of such compounds with any CA isoform are known at present.

(ii) The physiologically dominant cytosolic isoform hCA II was, on the other hand, effectively inhibited by all complexes 3 and $4\left(K_{\mathrm{I}}\right.$ values of 2.0-17.7 nM), except 3c, which was a medium potency inhibitor $\left(K_{\mathrm{I}}\right.$ of $110 \mathrm{nM}$, Table 2$)$. In this case, metal complexes $\mathbf{3}$ and $\mathbf{4}$ were much more effective hCA II inhibitors compared to the corresponding ligands from which they were obtained of type $\mathbf{1}$ and $\mathbf{2}$ (which showed inhibition constants in the range $267-720 \mathrm{nM}){ }^{25}$ Again, it is difficult to rationalize these results without detailed X-ray 
Table 2 The inhibition of human (h)CA isozymes I, II, IX and XII with sulfonamides $\mathbf{1}$ and $\mathbf{2}$, and their corresponding Gd(III) complexes 3 and $\mathbf{4}$, by a stopped-flow, $\mathrm{CO}_{2}$ hydrase assay. ${ }^{29}$ Data for the standard sulfonamide CAIs AAZ, EZA and $\mathbf{S}$ are also included for comparison

\begin{tabular}{lllll}
\hline & \multicolumn{4}{c}{$K_{\mathrm{I}} / \mathrm{nM}^{a}$} \\
\cline { 2 - 5 } Compound & hCA I & hCA II & hCA IX & hCA XII \\
\hline 1a & 970 & 298 & 110 & 14 \\
$\mathbf{1 b}$ & 425 & 720 & 41 & 38 \\
$\mathbf{1 c}$ & 88 & 290 & 27 & 39 \\
$\mathbf{2 a}$ & 2130 & 360 & 96 & 17 \\
$\mathbf{2 b}$ & 390 & 267 & 36 & 40 \\
$\mathbf{2 c}$ & 367 & 280 & 20 & 17 \\
$\mathbf{3 a}$ & 680 & 5.5 & 34 & 89 \\
$\mathbf{3 b}$ & 1600 & 9.5 & 27 & 38 \\
$\mathbf{3 c}$ & 7700 & 110 & 98 & 38 \\
$\mathbf{4 a}$ & 560 & 13 & 32 & 20 \\
$\mathbf{4 b}$ & 380 & 2.0 & 37 & 67 \\
$\mathbf{4 c}$ & 750 & 17.7 & 40 & 55 \\
AAZ & 250 & 12 & 25 & 5.7 \\
EZA & 25 & 8 & 34 & 22 \\
S & 21000 & 160 & 33 & 3.2
\end{tabular}

${ }^{a}$ Errors in the range $\pm 5 \%$ of the reported data from three different assays.

crystal structures of the complexes of hCA II with this type of inhibitor. Both DOTA-Gd(III) and TETA-Gd(III) conjugates lead thus to very effective hCA II inhibitors. This enzyme is, in fact, a drug target itself for obtaining diuretics, antiglaucoma and/or antiobesity agents. ${ }^{1}$

(iii) The transmembrane, tumor-associated enzyme CA IX was also inhibited by all Gd(III) complexes reported here, with $K_{\mathrm{I}}$ values in the range 27-98 $\mathrm{nM}$ (Table 2). The metal complexes are thus more effective hCA IX inhibitors than their parent ligands, from which they have been prepared. Both the DOTA and TETA derivatives showed similar efficacy, the main factor influencing the inhibitory activity being the sulfonamide head group present in these molecules. Indeed, the 4-substituted benzenesulfonamide derivatives (3a, 3b, 4a and 4b) were slightly better inhibitors compared to the 3 -substituted benzenesulfonamides ( $\mathbf{3} \mathbf{c}$ and $\mathbf{4 c}$ ) for both sub-series. It should be noted that these metal complexes show the same CA IX inhibitory activity as the clinically-used sulfonamides AAZ and EZA.

(iv) hCA XII is also inhibited by Gd(III) complexes 3 and $\mathbf{4}$ reported here, with $K_{\mathrm{I}}$ values in the range $20-89 \mathrm{~nm}$, but the complexes are generally weaker inhibitors compared to the corresponding sulfonamide from which they were prepared.

Thus, both tumor-associated isoforms hCA IX and XII are effectively inhibited by the Gd(III)-sulfonamide conjugates reported here, but these compounds do not act as selective inhibitors for tumor-associated CAs, as hCA II is also highly inhibited by most of them. However, as cytosolic CAs seem to be also involved in tumorigenesis, ${ }^{36}$ we decided to investigate the activity of some of these Gd(III) derivatives in vitro in cell cultures of hypoxic tumors overexpressing CAs. On the other hand, the presence of the $\mathrm{Gd}$ (III) ions in the new compounds reported here may lead to membrane-impermeable derivatives, as reported earlier by our group for positively-charged sulfonamides. ${ }^{37}$ Thus, ex vivo, the reported Gd(III)-sulfonamide conjugates may prevalently inhibit only the transmembrane isoforms, among which are also the tumor-associated examples CA IX and XII.

\section{Reduction of tumor acidosis}

As shown in Fig. 3, two of the effective hCA IX/XII inhibitors detected here, i.e., $\mathbf{3 b}$ and $\mathbf{4 b}$, were investigated for the inhibition of extracellular tumor acidification in two cell lines: the colorectal HT-29 and cervical HeLa carcinoma cell lines, both of which overexpress high amounts of CA IX under hypoxic conditions through the HIF-1 activation cascade described in Fig. 1. $\mathbf{S}$ was used as a control in these experiments, being shown earlier ${ }^{16-18}$ to reduce extracellular acidosis due to CA IX inhibition.

It may be observed that in both cell lines, the three investigated sulfonamides reduced acidosis only under hypoxic conditions when CA IX/XII were overexpressed, due to the binding of the inhibitor within the enzyme active site. In the blank experiments, the medium was acidified by about $0.48 \mathrm{pH}$ units for the HT-29 cell line and by about $0.30 \mathrm{pH}$ units for the HeLa cell line. Inhibition of the enzyme by sulfonamides lead to the slight but significant $(P<0.01)$ effect of reducing this acidosis by around $0.10-0.20 \mathrm{pH}$ units. Complex $\mathbf{4 b}$ was the most effective compound against HT-29, whereas $\mathbf{S}$ was the most effective against HeLa cells. Although modest, this effect might be enhanced by using the complementary targeting of the tumors by means of a combination therapy, in which the $\mathrm{CAI}$ is combined either with radiation or with other antitumor
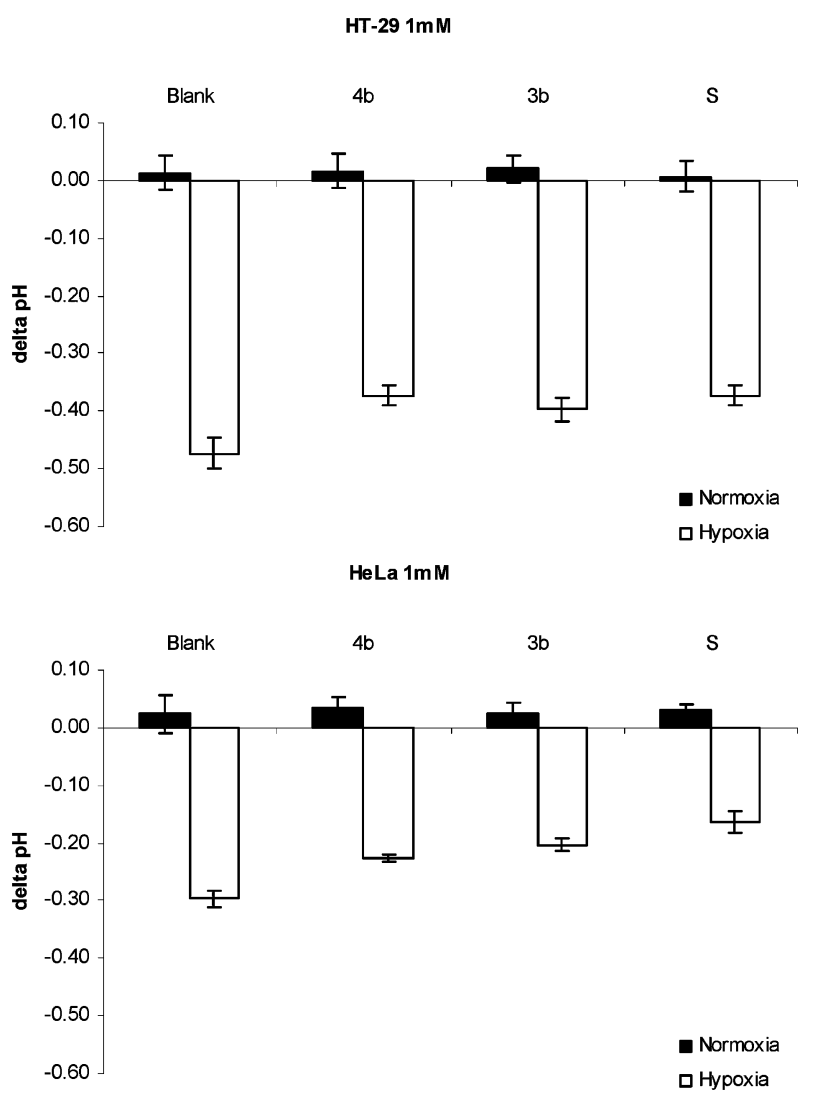

Fig. 3 The decrease of tumor cell extracellular acidosis in HT-29 and HeLa cell cultures treated with Gd(III) sulfonamide conjugates $\mathbf{4 b}$, $\mathbf{3 b}$ and $\mathbf{S}$ as a standard ${ }^{16}$ under normoxic and hypoxic conditions. 
agents possessing a different mechanism of action. ${ }^{19}$ Studies are in progress in several laboratories to demonstrate the efficacy of such a combination therapy of CAIs with other antitumor agents or radiation.

\section{Conclusion}

We have reported here for the first time that Gd(III)-sulfonamide complexes incorporating the macrocyclic ring systems DOTA or TETA are remarkable inhibitors of both tumor-associated CA isozymes CA IX and XII, being able to reduce tumor acidosis in vitro. This new class compound thus promises applications in the diagnostic and treatment of hypoxic tumors, which are largely non-responsive to classical chemoand radiotherapy.

\section{Acknowledgements}

This research was financed in part by a grant from the 6th Framework Programme of the European Union (DeZnIT project, to C. T. S. and A. S.) and by a 7th Framework Programme of the European Union grant (METOXIA). The authors thank Prof. Joulia Larionova (Institut Charles Gerhardt, Montpellier, France) for performing the magnetic measurements and Dr Marlies Oostendorp (University of Maastricht, The Netherlands) for determining the relaxivity values.

\section{References}

1 C. T. Supuran, Nat. Rev. Drug Discovery, 2008, 7, 168-181.

2 J.-Y. Winum, M. Rami, A. Scozzafava, J.-L. Montero and C. T. Supuran, Med. Res. Rev., 2008, 28, 445.

3 A. Cecchi and C. T. Supuran, Curr. Pharm. Des., 2008, 14, 699.

4 C. T. Supuran, Curr. Pharm. Des., 2008, 14, 601.

5 A. Scozzafava, A. Mastrolorenzo and C. T. Supuran, Expert Opin. Ther. Pat., 2004, 14, 667.

6 S. Pastorekova, S. Parkkila, J. Pastorek and C. T. Supuran, J. Enzyme Inhib. Med. Chem., 2004, 19, 199.

7 A. Scozzafava, A. Mastrolorenzo and C. T. Supuran, Expert Opin. Ther. Pat., 2006, 16, 1627.

8 M. Hilvo, L. Baranauskiene, A. M. Salzano, A. Scaloni, D. Matulis, A. Innocenti, A. Scozzafava, S. M. Monti, A. Di Fiore, G. De Simone, M. Lindfors, J. Janis, J. Valjakka, S. Pastorekova, J. Pastorek, M. S. Kulomaa, H. R. Nordlund, C. T. Supuran and S. Parkkila, J. Biol. Chem., 2008, 283, 27799.

9 C. T. Supuran and A. Scozzafava, Expert Opin. Ther. Pat., 2002, 12, 217.

10 C. T. Supuran, A. Scozzafava and A. Casini, Med. Res. Rev., 2003, 23, 146.

11 A. J. Kivelä, S. Parkkila, J. Saarnio, T. J. Karttunen, J. Kivelä, A. K. Parkkila, S. Pastoreková, J. Pastorek, A. Waheed, W. S. Sly and H. Rajaniemi, Histochem. Cell Biol., 2000, 114, 197.

12 C. C. Wykoff, N. J. Beasley, P. H. Watson, K. J. Turner, J. Pastorek, A. Sibtain, G. D. Wilson, H. Turley, K. L. Talks,
P. H. Maxwell, C. W. Pugh, P. J. Ratcliffe and A. L. Harris, Cancer Res., 2000, 60, 7075.

13 M. C. Brahimi-Horn and J. Pouysségur, Essays Biochem., 2007, 43, 165.

14 M. Bartošová, S. Parkkila, K. Pohlodek, T. J. Karttunen, S. Galbavy, V. Mucha, A. L. Harris, J. Pastorek and S. Pastorekova, J. Pathol., 2002, 197, 314.

15 V. Alterio, M. Hilvo, A. Di Fiore, C. T. Supuran, P. Pan, S. Parkkila, A. Scaloni, J. Pastorek, S. Pastorekova, C. Pedone, A. Scozzafava, S. M. Monti and G. De Simone, Proc. Natl. Acad. Sci. U. S. A., 2009, 106, 16233.

16 E. Švastová, A. Hulíková, M. Rafajová, M. Zat'ovičová, A. Gibadulinová, A. Casini, A. Cecchi, A. Scozzafava, C. T. Supuran and J. Pastorek, FEBS Lett., 2004, 577, 439.

17 L. Dubois, K. Douma, C. T. Supuran, R. K. Chiu, M. A. M.J. van Zandvoort, S. Pastoreková, A. Scozzafava, B. G. Wouters and P. Lambin, Radiother. Oncol., 2007, 83, 367.

18 L. Dubois, N. G. Lieuwes, A. Maresca, A. Thiry, C. T. Supuran, A. Scozzafava, B. G. Wouters and P. Lambin, Radiother. Oncol., 2009, 92, 423.

19 J. K. J. Ahlskog, C. E. Dumelin, S. Trüssel, J. Marlind and D. Neri, Bioorg. Med. Chem. Lett., 2009, 19, 4851.

20 J. K. Ahlskog, C. Schliemann, J. Mårlind, U. Qureshi, A. Ammar, R. B. Pedleym and D. Neri, Br. J. Cancer, 2009, 101, 645.

21 S. Aime and P. J. Caravan, J. Magn. Reson. Imaging, 2009, 30, 1259.

22 L. Lattuada and G. Lux, Tetrahedron Lett., 2003, 44, 3893.

23 A. Barge, G. Cravotto, E. Gianolio and F. Fedeli, Contrast Media Mol. Imaging, 2006, 1, 184.

24 S. Aime, D. D. Castelli, S. G. Crich, E. Gianolio and E. Terreno, Acc. Chem. Res., 2009, 42, 822.

25 M. Rami, A. Cecchi, J.-L. Montero, A. Innocenti, D. Vullo, A. Scozzafava, J.-Y. Winum and C. T. Supuran, ChemMedChem, 2008, 3, 1780.

26 E. A. L. Boudreaux and N. Mulay, Theory and Applications of Molecular Paramagnetism, John Wiley \& Sons, New York, 1976, pp. $125-147$.

27 C. Rorden and M. Brett, Behav. Neurol., 2000, 12, 191.

28 E. M. Haacke, R. W. Brown, M. R. Thompson and R. Venkatesan, Introductory Signal Acquisition Methods: Induction Decay, Spin Echoes, Inversion Recovery and Spectroscopy, in Magnetic Resonance Imaging: Physical Principles and Sequence Design, John Wiley \& Sons, Inc., New York, 1999, pp. 111-138.

29 R. G. Khalifah, J. Biol. Chem., 1971, 246, 2561.

30 S. Pastorekova, A. Casini, A. Scozzafava, D. Vullo, J. Pastorek and C. T. Supuran, Bioorg. Med. Chem. Lett., 2004, 14, 869.

31 G. De Simone, R. M. Vitale, A. Di Fiore, C. Pedone, A. Scozzafava, J. L. Montero, J. Y. Winum and C. T. Supuran, J. Med. Chem., 2006, 49, 5544.

32 B. L. Wilkinson, L. F. Bornaghi, T. A. Houston, A. Innocenti, C. T. Supuran and S.-A. Poulsen, J. Med. Chem., 2006, 49, 6539.

33 J. Y. Winum, C. Temperini, K. El Cheikh, A. Innocenti, D. Vullo, S. Ciattini, J. L. Montero, A. Scozzafava and C. T. Supuran, J. Med. Chem., 2006, 49, 7024.

34 J.-Y. Winum, S. A. Poulsen and C. T. Supuran, Med. Res. Rev., 2009, 29, 419.

35 A. Maresca, C. Temperini, H. Vu, N. B. Pham, S. A. Poulsen, A. Scozzafava, R. J. Quinn and C. T. Supuran, J. Am. Chem. Soc., 2009, 131, 3057.

36 P. Roy, E. Reavey, M. Rayne, S. Roy, M. Abed El Baky, Y. Ishii and C. Bartholomew, FEBS J., 2010, 277, 441.

37 A. Scozzafava, F. Briganti, M. A. Ilies and C. T. Supuran, J. Med. Chem., 2000, 43, 292. 